\title{
The Impact of Emotional Intelligence on Vocational Interests among Palestinian Students
}

\author{
Bassam Yousef Ibrahim Banat ${ }^{1}$, Omar Rimawi ${ }^{2} \&$ Mohammed Namourah $^{3}$ \\ ${ }^{1}$ Department of Applied Sociology, Al-Quds University, Jerusalem- Abu Dies, Palestine \\ ${ }^{2}$ Department of Psychology, Al-Quds University, Jerusalem- Abu Dies, Palestine \\ ${ }^{3}$ Department of Educational Sciences, Al-Quds Open University, Palestine \\ Correspondence: Bassam Yousef Ibrahim Banat, Department of Applied Sociology, Faculty of Arts, Al-Quds \\ University, Main Campus, Jerusalem- Abu Dies, Palestine. Tel: 970-2252-2727. E-mail: bbanat@staff.alquds.edu \\ orbassambanat@yahoo.com
}

Received: February 1, 2019

Accepted: February 20, 2019

Online Published: February 28, 2019

doi:10.5539/ass.v15n3p58

URL: https://doi.org/10.5539/ass.v15n3p58

\begin{abstract}
The purpose of the study was to identify the impact of emotional intelligence on vocational interests among Palestinian students. A sample of 333 students in the southern Hebron district participated in the study. Data was analysed using SPSS. The results showed that Palestinian students had a high level of emotional intelligence and a moderate level of vocational interests. Emotional intelligence appeared as an innovative prediction of vocational interests. The consequences of the findings for practice are highlighted.
\end{abstract}

Keywords: emotional intelligence, vocational interests, career, Palestine, students

\section{Introduction}

Emotional intelligence has attracted great interest from scientists around the world in light of its importance and impact on personality, performance, strength, and student development (Gardner, 1983; Mayer \& Salovey, 1990; Goleman, 1995, 2009; Vincent, 2003; Khawaldeh, 2004; Abu Rayyash et al., 2006; Joshi et al., 2012).

Numerous published studies have dealt with emotional intelligence and its various models due to the great developments observed in this era and the subsequent goals, as we are in an era where we are competing with time, space, high aspirations and cultural variations.

Vocational tendency is one of the most important factors that aids an individual to decide his/her field of study. If an individual scientifically deliberates the decision on the basis of vocational interests, it would enable one to succeed in life and be innovative in the field of choice. Each individual has job preferences based on his/her personal interests and desires (Tortillas, 1999; Aldahri, 2005).

People tend to prefer a vocation that helps them attain their goals such as living a good life, nutrition, housing, security, a good position in the community and so on. It is during adolescence that a call is for some people the most important step in life, while for others, it is a fairly important step that can be changed and made more flexible at all times. Choosing a vocation also leads to one selecting a lifestyle (Deniz et al., 2014).

Vocational interest is a fundamental factor, which serves as a guide and directs individuals to select their fields of specialty, which eventually culminates in success and develops their creativity (Turner \& Lapan, 2005).

\section{Background and Literature Review}

\subsection{Emotional Intelligence}

Emotional intelligence was rooted in social intelligence and was introduced for the first time by Thorndike in 1920 to refer to the ability to understand and handle people and to act wisely in human relations (Hafiz, 2011; Ghaonta \& Kumar, 2014). However, Gardner's writings (1983) on human intelligence and his theory of multiple intelligences have paved the way for the widespread define of emotional intelligence.

Gardner (1983) introduced the idea of multiple intelligences, which included both interpersonal intelligence and intrapersonal intelligence. However, Mayer and Salovey, the first to provide a definition of the term emotional intelligence as 'a form of social intelligence that involves the ability to monitor their own and others' feelings, to 
distinguish between them and use the information to guide one's thoughts and actions' (1993, p. 433). Additionally, they suggested a model with four-branches of emotional intelligence, which considers emotions as useful sources that help one make sense of and navigate the social environment, that are perceiving emotions, using emotions, understanding emotions, and managing emotions.

Furthermore, Goleman expanded the model to four branches after incorporating Mayer and Salovey's (1990) five essential elements of emotional intelligence, that are emotional self-knowledge, self-regulation, motivation, empathy, and social skills.

\subsection{Vocational Interests}

Vocational interests are personality indicators in work, studies, hobbies, leisure activities and choices (Holland, 1985). A person responds to particular vocational interests, general subjects and activities with responses such as 'I like it', 'I don't like it' or 'It doesn't matter' (Savickas, 1999). Despite the various views, there are many common problems regarding the definition of vocational interest. Based on the above, vocational can be defined as an actual process in which a person voluntarily attaches importance to an object without a particular effort, carries out that attention for an extended period of time and is aware of it and converts it into an answer and attitude.

Vocational interests can be classified as expressed and measured. The expressed interests are generally determined by answers derived from open questions. Measured interests arise when people discover their professional choices better than a professional interest list. Although there are several methods used to measure their professional interests, the most widely used method is a list of interests. The statement of interests is widely used for a person to express their interest by registering and comparing different vocations (Deniz, 2013).

Several studies have revealed that comprehending vocational interests helps to guide the individual in determining the decisions that must be owned in every stage of vocational growth. An understanding of the evolution of vocational interests helps counsellors to intervene in a timely and effective manner in order to modify any defect in vocational growth (Namourah, 2016).

Emotional intelligence and vocational interest are topics of popular discussion in humanities. In a recent study, Kurdish and Korkmaz (2018) indicated that emotional intelligence was considered as observed variable, and emotional instability was a positive prediction for career decision difficulties.

Di Fabio's study (2017) concluded that emotional intelligence is an innovative variable in career decision making. In the same context, Kemboi et al. (2016) stated that there was a correlation between personality types and professional choice.

The results in Huhtala's (2016) study have supported the idea that training courses for the development of emotional intelligence can be resources that can be used by career counsellors when advising people who are exploring their career path. Liu et al. (2014) revealed that professional maturity was positively correlated with the achievement of work, and both emotional intelligence and social professional interest reinforced the positive relationship between professional maturity and work performance.

Furthermore, the relationship between character strength and vocational interests has been tested by Proyer et al. (2012). The results showed that intellectual forces have created primary relationships with investigative and artistic interests, and social interests correlated with forces of transcendence and forces directed at others and career interests with forces.

Finally, Dahl and Cilliers (2012) concluded that neither cognitive ability nor any aspect of emotional intelligence predicted a change in negative career thinking. However, Puffer's study (2011) revealed that emotional intelligence is a prominent prediction for professional personality.

To sum up, the choice of careers is a national problem. Previous studies reported that post-secondary education statistics revealed that $20 \%$ to $60 \%$ of the freshmen class were undecided or uncertain of their career choice (Goleman, 2009, p. 18; Ghaonta \& Kumar, 2014; Namourah, 2016).

\section{Purpose and Scope}

The study addressed the impact of emotional intelligence on vocational interests among Palestinian students. Emotional intelligence is one of the most important aspects of the personality, which plays an active role in guiding and directing people to choose their specialties, leading to success and developing their creativity. The study is considered a pioneer to the authors' knowledge, and has shown that emotional intelligence and vocational interests, through empirical study, were relatively limited in the occupied Palestinian community, where the unemployment rate among undergraduates is considered a risk factor. 


\section{Hypothesis}

Based on the revised literature, the study proposed the following hypothesis:

Is there any impact of emotional intelligence on vocational interests among Palestinian students?

\section{Methods}

\subsection{Approach}

The study adopted the quantitative research method. The questionnaire is suitable for the exploratory nature of the research.

\subsection{Population and Sampling}

The target population consisted of high school students in southern Hebron district during the 2018/2019 academic year, which included 2485 students - 968 males for 1517 females (Palestinian Ministry of Education, 2018).

The total sample included 333 students (130 men and 203 women) in the southern Hebron district. The sample was chosen based on gender and stream. Sample size was calculated using an online tool: http://www.surveysystem.com/sscalc.htm, sample size calculator, with a margin error of 0.05 .

\subsection{Instrumentation}

Emotional intelligence was assessed using a 33-point scale index introduced by Schutte et al. (1998), while vocational interests were assessed using a 42-point scale index introduced by the Netherlands (1997) and taking into account the cultural appropriateness of the Palestinian community. A 5-point Likert scale was used to measure the responses (always, often, neither, rarely, never). Participants in selected high schools in the southern Hebron district were asked to complete the questionnaire. The sample survey tool searched for basic information about the participants in gender, stream, family birth rank, and grade point average (GPA).

\subsubsection{Instrument Validity}

The instrument validation was measured in two different phases. The initial phase involved a group of experts who provided feedback on the tool. The second phase involved the implementation of a pilot study $(\mathrm{N}=50)$ to validate the study tool using exploratory factorial analysis. Factor loading for all items exceeded 0.75 (from 0.78 to 0.89 ), which implied that these elements were capable of measuring any element of emotional intelligence and vocational interest among the sampled population.

\subsubsection{Instrument Reliability}

Reliability was tested using Cronbach's Alpha coefficient to determine the reliability and consistency of the study findings. Cronbach's Alpha for emotional intelligence and vocational interest were $(0.90 ; 0.92)$ respectively, demonstrating excellent reliability and consistency.

The participants' demographic distribution was as follows: gender, stream, family birth rank and GPA. Overall, the sample contained 333 students. Participants' GPA was between 65 and 95 points (M 76.70 SD 10.72). The females represented $61.0 \%$ of the participants, while the remaining $39 \%$ were males. The sample was drawn by artistic and scientific streams. The arts accounted for $67.3 \%$ of the sample, while $32.7 \%$ were the natural sciences, and half (57.9\%) of the participants were of middle family birth rank.

\subsection{Data Analysis}

The questionnaire items were evaluated on a 1-5 Likert scale (never to always), the highest score indicated a high level of emotional intelligence and vocational interests. Descriptive statistics measured emotional intelligence and vocational interests among the sampled population using Pearson correlation, Cronbach's Alpha and Factor Analysis through SPSS.

\section{Findings}

The results revealed that participants experienced a high level of emotional intelligence and a moderate level of vocational interests. The mean scores and standard deviation were (M 3.72, SD 0.34; M 3.44, SD 0.74) respectively.

In addition, the results showed a statistically significant positive correlation between emotional intelligence and vocational interests among Palestinian students, where the $\mathrm{R}$-correlation was $(0.574, \mathrm{P}=0.000)$. It was discovered that as emotional intelligence increases, vocational interests grow and vice versa. 


\section{Discussion and Recommendations}

The findings of the study revealed the effect of emotional intelligence in innovative vocational interests among Palestinian students. This result is considered a very important element in the Palestinian society, taking into consideration the difficulties the Palestinian educational system faces in terms of the high unemployment rate among graduated students that exceeded $45 \%$ among science graduates and $65 \%$ among arts graduates under the on-going Israeli occupation, which created negative trends among the students toward vocational interests (Namourah, 2016). However, Emotional intelligence is considered an important dimension in the correspondence between success, in general, and, in particular, vocational interests. Emotionally intelligent students have the ability to feel comfortable with themselves and others; they have the ability to understand, perceive and monitor their feelings (Banat \& Rimawi, 2014). This would lead them to possessing a sense of stability and calm and psychological ease that would positively affect their spirits and motivate them to increase their vocational interests. The results have different implications with regard to emotional intelligence as a prediction of vocational interests for parents, teachers, social advisors, and decision makers.

Furthermore, being emotionally intelligent is an important stage in the formation and development of one's personality; it represents a turning point in the lives of students who aim to fulfil their desires, abilities, preferences and interests. Emotional intelligence also encounters the social interaction that contributes to the development of students' personalities; it enhances their learning skills and thinking; and helps in decision making (Banat \& Rimawi, 2014) and vocational interests.

Moreover, when emotional intelligence has proven to be an important indicator of vocational interests, this reflects how the affective domain, the environment, creativity, self-perception, career desires and interpersonal skills help to make well-informed choices beyond the cognitive domain of being emotionally intelligent. Based on the results of this study, the following recommendations were formulated:

1. Update the Palestinian educational system with emotional intelligence as an innovative component of vocational interests.

2. Encourage the exchange of knowledge on emotional intelligence among students in general and students seeking professional guidance, in particular using modern techniques.

3. Further studies are recommended to establish a clearer understanding of emotional intelligence and vocational interests among Palestinian students.

\section{References}

Abu Rayyash, H., Safi, A., Emoor, O., \& Sharif, S. (2006). Motivation and emotional intelligence. Amman: Dar Al-Fiker.

Aldahri, S. (2005). The psychology of vocational guidance and theories. Amman: Wail for the deployment of Jordan (Arabic version).

Banat, B., \& Rimawi, O. (2014). The impact of emotional intelligence on academic achievement of Al- Quds University students. International Humanities Studies, 1(2), 12-39. Retrieved from http://ihs-humanities.com/journals/vol1_no2_july2014/2.pdf

Dahl, D., \& Cilliers, F. (2012). The relationship between cognitive ability, emotional intelligence and negative career thoughts: A study of career-exploring adults. SA Journal of Human Resource Management, 10(2), 1-14. https://doi.org/10.4102/sajhrm.v10i2.461

Deniz, K. (2013). National standardization of the occupational field interest inventory (OFII) for Turkish culture according to age and gender. Eurasian Journal of Educational Research, 50(1), 163-184. Retrieved from https://files.eric.ed.gov/fulltext/EJ1059928.pdf

Deniz, K., Türe, E., Uysal, A., \& Akar, T. (2014). Investigation of vocational interest and vocational preference in terms of gender and socio-economic status. Eurasian Journal of Educational Research, 57(1), 91-112. Retrieved from https://files.eric.ed.gov/fulltext/EJ1056255.pdf

Di Fabio, A. (2017). Emotional intelligence: A new variable in career decision-making. Florence: University of Florence. Retrieved from https://pdfs.semanticscholar.org/decd/2a39c8f1dea89c1e100d4f04ae57e6d96b2b. pdf?_ga=2.68042001.1810002369.1546277576-1681185595.1546277576

Gardner, H. (1983). Frames of mind. New York: Basic Books.

Ghaonta, I., \& Kumar, P. (2014). Emotional intelligence as related to gender, stream and social intelligence. Journal of Educational Studies, Trends \& Practices, 4(1), 76-87. Retrieved from 
http://www.mierjs.in/ojs/index.php/mjestp/article/view/67/67

Goleman, D. (1995). Emotional intelligence: Why it can matter more than IQ. New York: Bantam Books.

Goleman, D. (2009). Working with emotional intelligence. New York: Bantam Books.

Hafiz, N. (2011). Emotional intelligence and its relationship to adaptive behavior and academic achievement among a sample of children from an orphanage in Holy Mecca (Master's Thesis). Mecca: Umm Al-Qura University.

Holland, J. (1985). Making vocational choices: A theory of vocational personalities and work environments (2nd ed.). USA: Prentice Hall.

Holland, J. (1997). Making vocational choices. Odessa, FL: Psychological Assessment Resources, Inc.

Huhtala, H. (2016). Emotional intelligence and career decisiveness (Master's Thesis). California: California State University. Retrieved from https://csus-dspace.calstate.edu/bitstream/handle/10211.3/182664/Thesis\% 20draft.pdf?sequence $=1$

Joshi, S., Srivastava, K., \& Raychaudhuri, A. (2012). A descriptive study of emotional intelligence and academic performance of MBBS students. Procedia-Social and Behavioral Sciences, 69(1), 2061-2067. https://doi.org/10.1016/j.sbspro.2012.12.165

Kemboi, R., Kindiki, N., \& Misigo, B. (2016). Relationship between personality types and career choices of undergraduate students: A case of Moi University, Kenya. Journal of Education and Practice, 7(3), 102-112. Retrieved from http://ir.mu.ac.ke:8080/xmlui/handle/123456789/414

Khawaldeh, M. (2004). Emotional intelligence. Amman: Dar Al-Shorouk.

Kırdök, O., \& Korkmaz, O. (2018). Dimensions of personality and emotional intelligence as predictors of high school students' career decision difficulties. Educational Research and Reviews, 3(12), 495-502. https://doi.org/10.5897/ERR2018.3532

Liu, Y., Peng, K., \& Wong, C. (2014). Career maturity and job attainment: The moderating roles of emotional intelligence and social vocational interest. International Journal for Educational and Vocational Guidance, 14(3), 293-307. https://doi.org/10.1007/s10775-014-9271-5

Mayer, J., \& Salovey, P. (1990). Emotional intelligence. Imagination, Cognition and Personality, 9(1), 185-211. https://doi.org/0.2190/DUGG-P24E-52WK-6CDG

Mayer, J., \& Salovey, P. (1993). The intelligence of emotional intelligence. Intelligence, 17(1), 433-442. https://doi.org/10.1016/0160-2896(93)90010-3

Namourah, M. (2016). Vocational interests among Palestinian students. International Humanities Studies, 3(3), 16-29. Retrieved from http://www.ihs-humanities.com/archive/2016/vol-3-no-3-september-2016

Palestinian Ministry of Education. (2018). Educational system: Facts and figures. Ramallah.

Proyer, R., Sidler, N., Weber, M., \& Ruch, W. (2012). A multi-method approach to studying the relationship between character strengths and vocational interests in adolescents. International Journal for Educational and Vocational Guidance, 12(2), 141-157. https://doi.org/10.1007/s10775-012-9223-x

Puffer, K. (2011). Emotional intelligence as a salient predictor for collegians' career decision making. Journal of Career Assessment, 19(2), 130-150. Retrieved from http://citeseerx.ist.psu.edu/viewdoc/download?doi=10.1.1.924.1508\&rep=rep1\&type=pdf

Savickas, M. (1999). The psychology of interests. In M. L. Savickas \& A. R. Spokane (Eds.), Vocational interests: Meaning, measurement and counseling use. USA: Davies-Black.

Schutte, N., Malouff, J., Hall, L., Haggerty, D., Cooper, J., Golden, C., \& Dornheim, L. (1998). Development and validation of a measure of emotional intelligence. Personality and Individual Differences, 25(2), 167-177. https://doi.org/10.1016/S0191-8869(98)00001-4

Thorndike, E. (1920). Intelligence and its use. Harper's Magazine, 140, 227-235. Retrieved from https://harpers.org/archive/1920/01/intelligence-and-its-uses/

Tortillas, F. (1999). Programmed instruction and employment in the classroom learning. Cairo: The Anglo-Egyptian Library.

Tsaousis, I., \& Nikolaoy, I. (2005). Exploring relationship of emotional intelligence with physical and psychological health functioning. Stress \& Health, 21(2), 77-86. https://doi.org/10.1002/smi.1042 
Vincent, D. (2003). The evaluation of a social emotional intelligence program: Effect of fifth grades prosocial and problem behaviors. Dissertation Abstracts International, 64(10), 3596-A.

\section{Copyrights}

Copyright for this article is retained by the author(s), with first publication rights granted to the journal.

This is an open-access article distributed under the terms and conditions of the Creative Commons Attribution license (http://creativecommons.org/licenses/by/4.0/). 